\title{
Effects of Parenteral Application of Fish Oil versus Soy Oil Emulsions on Bacterial Clearance Functions
}

\author{
$\begin{array}{llll}\text { I. Kelbel } & \text { T. Koch } & \text { A. Prechtl } & \text { A. Heller } \\ \text { b } & \text { E. Schlotzer } & \text { H.G. Schiefer } & \text { H. Neuhof } \\ & \end{array}$ \\ aUniversitätsklinik für Anästhesiologie, Universität Ulm, ${ }^{b}$ Klinik für Anästhesie und Intensivtherapie, Universität Dresden, \\ ${ }^{c}$ Abteilung für Klinische Pathophysiologie und Experimentelle Medizin/Zentrum für Innere Medizin, Universität Gießen, \\ 'Institut für Klinische Forschung, Fresenius AG, Bad Homburg, eInstitut für Medizinische Mikrobiologie, Universität Gießen
}

\author{
Key Words \\ Bacterial clearance $\cdot$ Fish oil $\cdot \omega-3$ fatty acids · Sepsis · \\ Soybean oil
}

\section{Summary}

Background: The aim of this study was to test whether or not infusion of triglycerides containing $\omega$-3 fatty acids (FAs) modifies immune function in terms of systemic clearance and organ distribution of injected Escherichia coli in a rabbit model. Materials and Methods: In groups of 6 rabbits each, a defined number of $E$. coli $\left(1.3 \times 10^{8}\right.$ colony-forming units, $\mathrm{CFU}$ ) was injected intravenously after 3 days of infusion with a lipid emulsion prepared from fish oil (Omegavenös ${ }^{\circledR} 10 \%, 1.5 \mathrm{~g} / \mathrm{kg}$ body weight/day), a soy oil preparation (Lipovenös ${ }^{\circledR} 10 \%, 1.5 \mathrm{~g} / \mathrm{kg}$ body weight/day), or after isotonic saline application (control). In order to compare dose-dependent effects, in a second experimental design a lower dose of each lipid emulsion $(0.5 \mathrm{~g} / \mathrm{kg}$ body weight) was infused over a 4-hour period before applicating E. coli. Parameters monitored were arterial pressure and rates of bacterial elimination from the blood. The animals were killed $3 \mathrm{~h}$ and $6 \mathrm{~h}$ after bacterial infection, respectively, and tissue samples of liver, spleen, lung, and kidney were collected for microbiological examinations. Results: Lipovenös infusion produced a significant delay in blood clearance compared with saline and Omegavenös treatment. The diminished systemic bacterial elimination after Lipovenös infusion was accompanied by increased numbers af viable bacteria in lung and spleen. In contrast to this, in the Omegavenös group bacterial counts in the lung did not increase and smaller amounts of viable bacteria were detected in organ homogenates 6 h after injection of E. coli. Conclusion: Compared with the soy oil preparation, $\omega$ - 3 FAs induce improved bacterial clearance from the blood that is associated with significantly lower numbers of $E$. coli in the lung. Thus, appropriate nutrition providing $\omega-3$ FA might serve as a pharmacological tool to improve host defence against bacterial infection in critically ill patients.

\author{
Schlüsselwörter \\ Bakterielle Clearance · Fischöl · $\omega$-3-Fettsäuren · Sepsis · \\ Sojaöl
}

\section{Zusammenfassung}

Hintergrund: Zur Abklärung von Einflußfaktoren, die zu einer Verbesserung der Fähigkeit des Organismus zur Klärung von Bakterien (Escherichia coli) aus dem Blut sowie zur Verbesserung der Phagozytosekapazität des retikuloendothelialen Systems führen, wurde diese Studie am Kaninchenmodell durchgeführt. Material und Methoden: Je 6 Versuchstieren wurde über einen Zeitraum von 3 Tagen in einer Gruppe eine Fettemulsion mit einem hohen Anteil an $\omega$-3-Fettsäuren (FS) auf Basis eines Fischöls (Omegavenös ${ }^{\circledR} 10 \%, 1,5 \mathrm{~g} / \mathrm{kg}$ Körpergewicht/Tag), ein Sojaöl-Präparat (Lipovenös ${ }^{\circledR} 10 \%, 1,5 \mathrm{~g} / \mathrm{kg}$ Körpergewicht/Tag), bzw. 0,9\% $\mathrm{NaCl}$ infundiert. Zum Vergleich dosisabhängiger Effekte wurde einmalig über einen Zeitraum von $4 \mathrm{~h}$ eine niedrigere Dosis Omegavenös10\% (0,5 g/kg Körpergewicht, $\mathrm{n}=6) \mathrm{bzw}$. Lipovenös $10 \%(0,5 \mathrm{~g} / \mathrm{kg}$ Körpergewicht, $\mathrm{n}=6)$ infundiert. Nach Beendigung der Infusion wurde unter kontinuierlicher Messung des arteriellen Drucks und der Blutgase 1,3 $\times 10^{8}$ koloniebildende Einheiten (CFU) E. coli i.v. appliziert und während der folgenden Stunden Blutkulturen sowie 3 bzw. $6 \mathrm{~h}$ nach Bakteriengabe Gewebeproben von Leber, Milz, Lunge und Niere zur mikrobiologischen Aufarbeitung entnommen. Ergebnisse: In den mit Lipovenös10\% behandelten Gruppen kam es im Vergleich zu den Kontrollen und den Omegavenös-Gruppen zu einer deutlichen Verlängerung der Elimination der Bakterien aus der Blutbahn, verbunden mit einer Zunahme der Bakterien in Lunge und Milz. Im Gegensatz dazu waren in den Omegavenös-Gruppen keine vermehrten Bakterienzahlen in der Lunge anzüchtbar, und es wurden in allen Gewebehomogenaten nach $6 \mathrm{~h}$ eine insgesamt niedrigere Bakterienzahl gefunden. Schlußfolgerung: $\omega-3-\mathrm{FS}$ scheinen die Bakterienelimination aus dem Blut günstig zu beeinflussen sowie eine unter Infusion mit $\omega-6$-FS auftretende Bakteriämie der Lunge zu verhindern. 
Chemotaxis

Activation of PMN

Vascular permeability $\uparrow$

Vascular tone $\Uparrow$

Activation of PMN

Platelet aggregability $\Uparrow$

Fig. 1. Influence of $\mathrm{AA}$ and $\mathrm{EPA}$ on immune function.

Vascular tone $\downarrow$

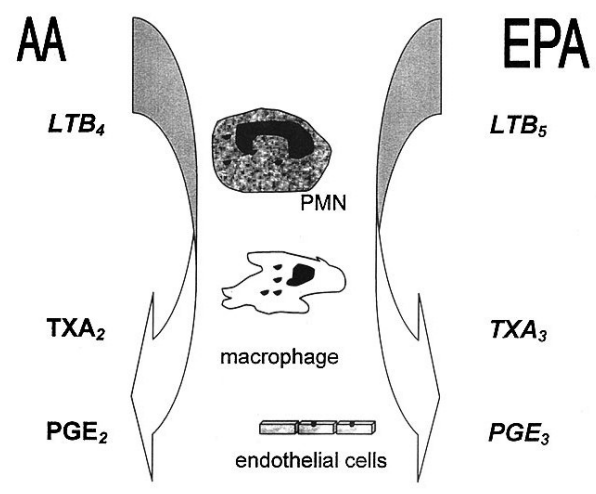

Activation of PMN

\section{Introduction}

Sepsis continues to be an important clinical problem associated with a high mortality rate. Shock and trauma predispose the host to an increased susceptibility to infection, which often leads to the adult respiratory distress syndrome or multiple organ failure [1].

The fact that a transient but profound depression of the reticuloendothelial system (RES) as well as intestinal barrier dysfunction has been observed after injury or surgical trauma suggests that the RES plays a major role in the pathogenesis of septic events. The reported pathomechanisms suggest that the incidence of septic complications may be initiated by a loss of gut barrier function, with invasion of great amounts of bacteria and endotoxin and may be due to an impairment of clearance functions that may be caused by reduced phagocytosis and the lysis capability of the RES. Recently, dietary enrichment of polymorphonuclear leukocytes (PMN) phospholipid pools with n-3 fatty acids (FAs), in particular with eicosapentaenoic acid (EPA), has attracted attention as a putative therapeutic regimen for dampening PMN- and eicosanoid-related inflammatory events.

IF $\omega$-3 FAs are included in the diet, EPA (C20:5n-3) competes with arachidonic acid (AA, C20:4n-6) on the cyclooxygenase and on the 5-lipoxygenase pathways. The metabolization of EPA results in a reduced generation of diene prostanoids (e.g. $\mathrm{PGE}_{2}, \mathrm{PGI}_{2}, \mathrm{TXA}_{2}$ ) and of tetraene leukotrienes (e.g. LTB 4 ), derived from $\mathrm{AA}$ in favor of the corresponding triene prostanoids (e.g. $\mathrm{PGE}_{3}, \mathrm{PGI}_{3}, \mathrm{TXA}_{3}$ ) and pentaene leukotriene $\left(\mathrm{LTB}_{5}\right)$ derived from EPA [2]. Examination of the EPA/AA ratio in several cells, i.e. erythrocytes [3], neutrophils [4, 5] platelets [6, 7] endothelial cells, monocytes as well as brain and liver cells [8], revealed that $\omega$-3 FAs are preferentially incorporated into membranes, resulting in an enhanced release of EPA-derived products with an attenuated spectrum of biological activity instead of those derived from AA [9-12], (fig. 1).

Our group recently demonstrated that, even after short-term infusion of a fish oil emulsion, $\omega-3$ FAs are metabolized and integrated into the phospholipid pool of cell membranes, therefore, leading to dampened inflammatory events [13-15].
Thus, modulation of eicosanoid synthesis may attenuate uncontrolled inflammatory reactions which ultimately may lead to organ failure. However, regulation of eicosanoid production is also of importance for maintenance of the systemic and cellular defense in the case of infection. When comparing nutritional solutions containing increased amounts of $\omega-6$ FAs with those containing $\omega$-3 FAs, a significant increase in cellular immune functions, e.g. opsonization index, was found following administration of $\omega-3$ FAs [16]. Thus, in a chronic model of sepsis, mortality was significantly reduced using diets supplemented with $\omega$-3 FAs [17]. The idea that the cellular and humoral defense might be impaired under preferential $\omega$ 6 FA application has been supported by in vitro experiments demonstrating that $\omega-6$ FA supplementation results in reduced phagocytosis activity and mitogen-induced proliferation of lymphocytes as well as suppressed synthesis of immunglobulins [18]. Based on these and other observations, appropriate nutritional support with $\omega-3$ FA-containing lipid emulsion may ameliorate the impaired immune functions after injury thus reducing the risk of sepsis. In case of sepsis $\omega-3$ FAs may also reduce the severity of the systemic inflammatory response to infection.

The present study was designed to investigate clearance function after parenteral application of a lipid emulsion prepared from fish oil (Omegavenös ${ }^{\circledR}$ ) in comparison with that of a soy oil preparation (Lipovenös ${ }^{\circledR}$ ) in a reproducible animal model. The central question addressed is whether $\omega-3$ FAs influence phagocytosis and lysis capacity of the RES and thereby reduce bacterial growth in blood and tissue. In order to simulate bacterial invasion into the intravascular space and to allow quantitative microbiological determinations, defined numbers of Escherichia coli (1.3 $\times 10^{8}$ colony-forming units, CFU) were injected intravenously after infusion of lipid emulsions or saline. The elimination kinetics of bacteria from the blood and their organ distribution in liver, spleen, kidney, and lung were studied.

\section{Materials and Methods}

This study was approved by the Animal Subject Protection Committee of the Faculty of Clinical Medicine Mannheim, University of Heidelberg. 
Care and handling of animals were in accordance with the principles expressed in the Helsinki Declaration.

\section{Rabbit Model}

Standard-breed rabbits of either sex weighing between 2,500 and 3,300 g were anesthetized with ketamine ( $50 \mathrm{mg} / \mathrm{kg}$ body weight) and xylazine (4 $\mathrm{mg} / \mathrm{kg}$ body weight) and anticoagulated with heparin-sodium (1,000 U/kg body weight) injected into an ear vein catheter. The animals were placed in a supine position on a tempered preparation table. After aseptic placement of a tracheostomy tube, the rabbits were mechanically ventilated with room air (tidal volume $30 \mathrm{ml}$, frequency 30 volumes/min) during the whole observation period by means of a Starling pump (B. Braun, Melsungen, Germany). A polyvinyl chloride catheter (inside diameter 1.4 $\mathrm{mm}$ ) was inserted into the right carotid artery for arterial pressure measurements and blood sampling. Anesthesia was maintained by continuous infusion of ketamine $(1-3 \mathrm{mg} / \mathrm{kg}$ body weight $/ \mathrm{h})$ in combination with $\mathrm{xy}$ lazine $(0.1-0.2 \mathrm{mg} / \mathrm{kg}$ body weight $/ \mathrm{h})$ under hemodynamic monitoring

\section{Monitoring}

Arterial and airway pressure were monitored on-line via Statham strain gauge transducers connected to a Servomed recorder (Hellige, Freiburg i.Br., Germany). Blood samples were drawn intermittently for measurements of $\mathrm{pH}, \mathrm{pO}_{2}, \mathrm{pCO}_{2}$, and $\mathrm{HCO}_{3}$ (ABL 330; Radiometer, Copenhagen, Denmark), hemoglobin and $\mathrm{O}_{2}$ saturation (OSM2; Radiometer), hematocrit (Adams Autokrit centrifuge; Clay-Adams, New York, NY, USA). Triglycerides were determined by an enzymatic calorimetric test using the commercial kit Triglyceride GPO-PAP (Boehringer Mannheim $\mathrm{GmbH}$, Mannheim, Germany)

\section{Experimental protocol}

72 rabbits were randomly assigned to different groups of 6 animals each. Two doses of lipid emulsion ranging between the lowest and highest dosage usually applied for parenteral nutrition with Lipovenös were chosen to study dose-dependent effects on bacterial clearance.

\section{High-Dose Group}

3-Hour Clearance. Animals were pretreated with $1.5 \mathrm{~g} / \mathrm{kg}$ body weight/day of a fish oil emulsion (Omegavenös, $n=6$ ), a soybean oil emulsion (Lipovenös, $\mathrm{n}=6$ ), or the equivalent volume of $0.9 \%$ saline (control, $\mathrm{n}=6$ ) for 3 consecutive days. The administered volume ranged from 42 to $48 \mathrm{ml}$, depending on the weight of the animal, and was infused within $90 \mathrm{~min}$ via the ear vein catheter. After termination of the third lipid or saline infusion a 30-min steady-state period of stable hemodynamics was followed and then E. coli $\left(1.3 \times 10^{8} \mathrm{CFU}\right)$ were injected via the ear vein catheter. Arterial blood was aseptically extracted for culture just before and after bacterial injection at 1,5, 10, 15, 20, 25, 30, 40, 50 and $60 \mathrm{~min}$, and thereafter at 30-min intervals. Blood gases, hematocrit, and hemoglobin were determined at hourly intervals. Additionally, blood samples were taken before and after lipid infusion as well as at the end of the experiments to investigate triglyceride levels. Three hours after bacterial injection, the animals were sacrificed with an overdose of pentobarbital, and, subsequently, tissue samples of liver, spleen, kidney, and lung were taken under aseptic conditions for bacterial counts.

6-Hour Clearance. In order to study the time course of bacterial killing in the blood and tissues, the same protocol as described above was performed, but with a prolonged observation period of $6 \mathrm{~h}$. As described, arterial blood was extracted for culture, blood gases, hematocrit, and hemoglobin concentration, and finally the tissue samples were drawn $6 \mathrm{~h}$ after E. coli injection.

\section{Low-Dose Group}

In a second experimental design low doses $(0.5 \mathrm{~g} / \mathrm{kg}$ of body weight) of Omegavenös, Lipovenös and saline, respectively, was given once prior to bacterial injection. The administered volume ranged from 12.5 to $16.5 \mathrm{ml}$ and was infused over a 4 -hour period via the ear vein catheter. Analo-

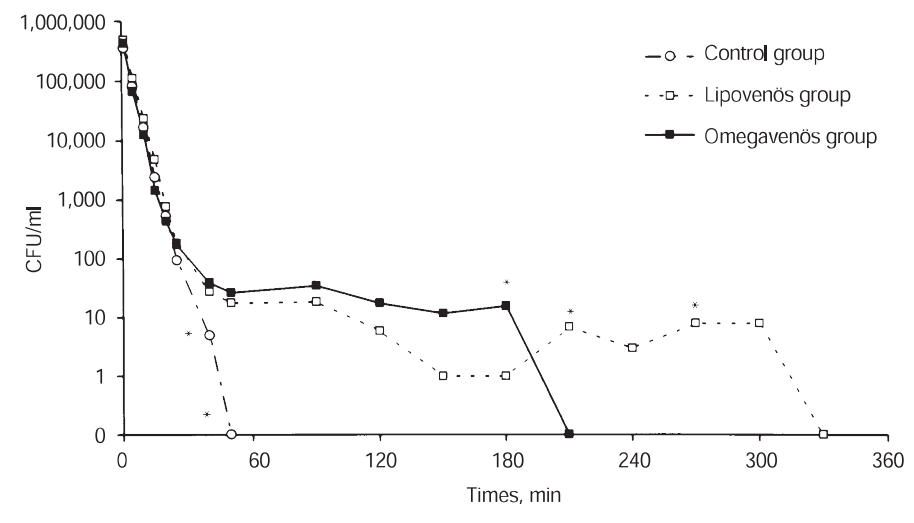

Fig. 2. Time course of bacterial elimination from blood after injection of E. coli $\left(1.3 \times 10^{8} \mathrm{CFU}\right)$ in the groups pretreated with high doses of lipids (1.5 g/kg body weight for 3 days). ${ }^{*}=\mathrm{p}<0.05$ versus all other groups (ANOVA).

gously to the other groups, bacteria $\left(1.3 \times 10^{8} \mathrm{CFU}\right.$ E. coli) were injected and subsequently blood samples were drawn for bacterial counts. Tissue samples were taken 3 and $6 \mathrm{~h}$ after $E$. coli injection, respectively.

\section{Quantitative Microbiology}

Immediately after organ collection, cooled blood and tissue samples were prepared for bacterial culture. Blood samples were diluted by serial dilution into defined volumes of sterile saline. $100 \mu \mathrm{l}$ of each dilution were plated in duplicate onto cysteine-lactose electrolyte-deficient agar plates as described by Sandys [19]. Aseptically collected organs were weighed, and representative samples (0.8-2 g) of each organ were homogenized in a mortar with $5 \mathrm{ml}$ sterile saline. Serial dilutions of tissue suspension (50 $\mu$ l) were plated onto cysteine-lactose electrolyte-deficient agar plates. The inoculated plates were incubated at $37^{\circ} \mathrm{C}$ for $24 \mathrm{~h}$, and bacterial counts, appearing as $\mathrm{CFU}$, were read. The final bacterial concentrations were calculated as the numbers of colonies/ml blood and of colonies/g harvested tissue.

\section{Materials}

The lipid emulsions Omegavenös 10\% prepared from fish oil and Lipovenös $10 \%$ produced from soy oil were gifts from Fresenius AG (Bad Homburg, Germany). Both are 10\% FA emulsions. The used batches of Omegavenös $10 \%$, rich in long-chain $\omega$-3 FAs, yielded the following final concentrations in the emulsion: EPA (C20:5n3) $19 \mathrm{mg} / \mathrm{ml}$, docosahexaenoic acid (C22:6n3) $25 \mathrm{mg} / \mathrm{ml}$, palmitic acid (C16:0) $12 \mathrm{mg} / \mathrm{ml}$, stearic acid (C18:0) $2.5 \mathrm{mg} / \mathrm{ml}$, oleic acid (C18:1n9) $14 \mathrm{mg} / \mathrm{ml}$, linoleic acid (C18:2n6) $2.7 \mathrm{mg} / \mathrm{ml}$, linolenic acid (C18:3n3) $0.7 \mathrm{mg} / \mathrm{ml}$, AA (C20:4n6) $2.2 \mathrm{mg} / \mathrm{ml}$, and other FAs $27.3 \mathrm{mg} / \mathrm{ml}$. The major components of Lipovenös $10 \%$, rich in $\omega-6 \mathrm{FAs}$, were linoleic acid $51 \mathrm{mg} / \mathrm{ml}$, linolenic acid $7.2 \mathrm{mg} / \mathrm{ml}$, oleic acid $22.4 \mathrm{mg} / \mathrm{ml}$, palmitic acid $12 \mathrm{mg} / \mathrm{ml}$, stearic acid $4 \mathrm{mg} / \mathrm{ml}$, and other FAs $10 \mathrm{mg} / \mathrm{ml}$

\section{Bacterial Inoculum}

E. coli - an encapsulated, serum-resistant, nonhemolytic strain freshly isolated from blood culture of a septicemic patient - were cultivated on blood agar plates. The grown colonies were scraped from the plates, carefully homogenized by vortexing in tryptic soy broth, serially diluted, and adjusted to a density of $1.3 \times 10^{8} \mathrm{CFU} / \mathrm{ml}$. They were stored in a freezer until use. The amount of exogenous $E$. coli used was based on pilot experiments, investigating the clearance and organ distribution of different doses of E. coli $\left(10^{10}, 10^{8}, 10^{6} \mathrm{CFU}\right)$. For this study, a dose was chosen 
Fig. 3. Counts of viable bacteria in spleen (a) and lung (b) homogenates taken $3 \mathrm{~h}$ and $6 \mathrm{~h}$ after injection of $E$. coli in the groups pretreated with high doses of lipid emulsions $\left(1.5 \mathrm{~g} / \mathrm{kg}\right.$ body weight for 3 days) $.^{*}=\mathrm{p}<0.01$ versus controls; ${ }^{* *}=\mathrm{p}<0.001$ versus all other groups.
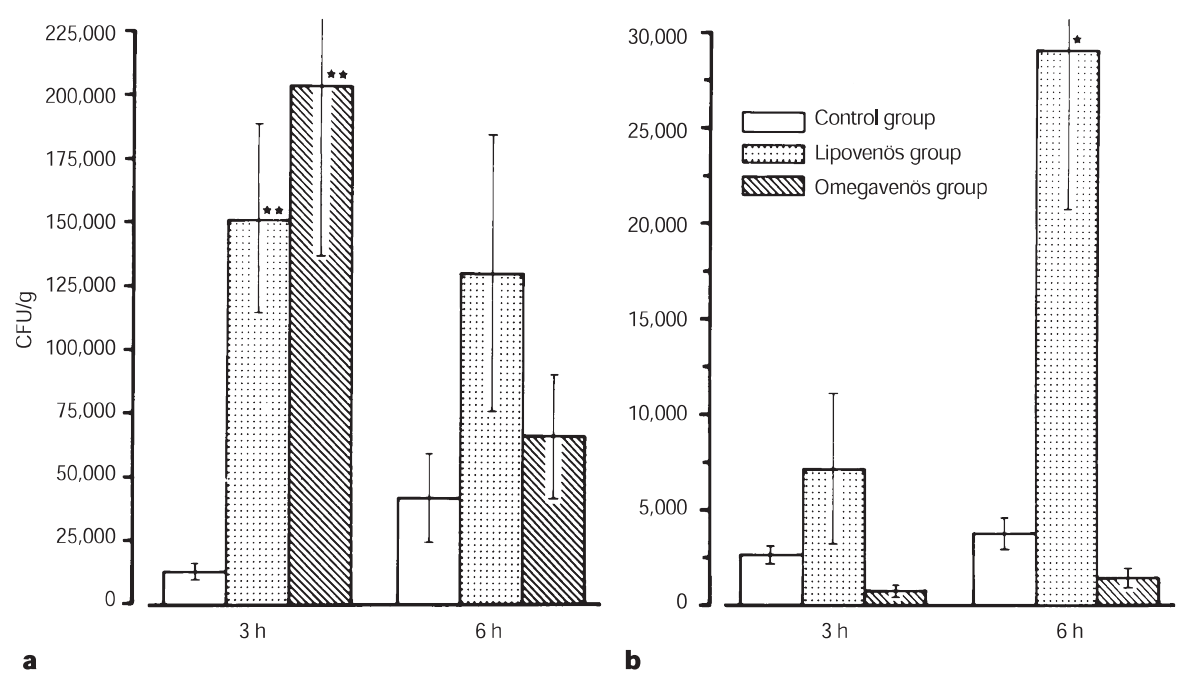

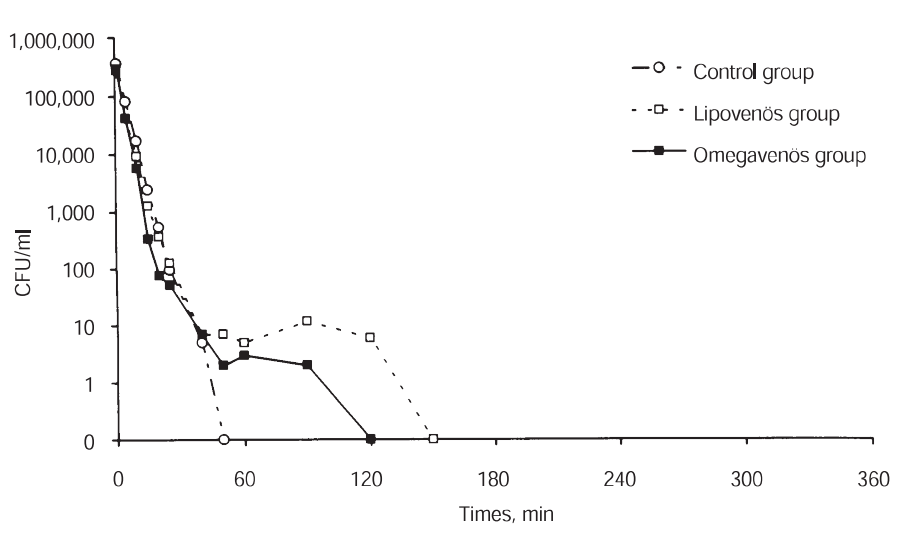

Fig. 4. Time course of bacterial elimination from blood after injection of E. coli $\left(1.3 \times 10^{8} \mathrm{CFU}\right)$ in the groups pretreated with low doses of lipids $(0.5 \mathrm{~g} / \mathrm{kg}$ body weight) .

which showed easily reproducible elimination kinetics, but did not induce severe hemodynamic changes influencing clearance function by tissue hypoperfusion. The applied dose of $1.3 \times 10^{8} \mathrm{E}$. coli was completely eliminated during a time period of 60-90 min in control animals and allowed registration of slight decreases as well as slight increases in elimination kinetics during the observation period. Delayed clearance at higher doses might be due to the measured depression of hemodynamics with increased vascular resistance, which was not the object of the present study. Shock-induced immunosuppression has been reported in previous studies $[20,21]$. Experiments with lower doses, however, demonstrated such a rapid bacterial elimination (within $10-15 \mathrm{~min}$ ) that possible minor increases in clearance function were not detectable. In order to exclude the possibility of bacterial translocation induced solely by soy oil or fish oil emulsion infusion in the absence of injected bacteria, experiments without exogenous bacteria were performed.

\section{Statistical Analysis}

Data are presented as arithmetic means \pm standard error (SEM). The logarithm of the quantitative bacterial count was used for statistical comparison. Differences between groups were tested by one-way analysis of variance and subsequently verified by LSD multiple comparison procedure. Significance was accepted at $\mathrm{p}<0.05$.

\section{Results}

Measurements of mean arterial pressure, blood gases $\left(\mathrm{pO}_{2}\right.$ $\mathrm{pCO}_{2}, \mathrm{O}_{2}$ saturation, $\mathrm{pH}$ ) as well as hematocrit and hemoglobin did not differ significantly from baseline values throughout the study period in the controls, Omegavenös- and Lipovenös-treated rabbits. The serum triglyceride levels did not increase in the groups treated with low doses of lipid emulsions (42-120 mg/dl), but were significantly elevated during high-dose infusion of Lipovenös and Omegavenös (up to $1,910 \mathrm{mg} / \mathrm{dl}$ and $2,820 \mathrm{mg} / \mathrm{dl}$, respectively). This increases in triglyceride levels during lipid infusion were followed by decreasing levels reaching baseline values within the following $360 \mathrm{~min}$.

No bacterial translocation into the circulating blood could be found after treatment with the various dosages of lipid emulsions and before $E$. coli injection as suggested by sterile cultures. In additional pilot experiments, we tested whether or not Lipovenös or Omegavenös treatment itself leads to invasion of E. coli, particularly from the gut, into the blood and other organs during the observation period. Sterile blood and organ cultures were found after soy oil and fish oil emulsion treatment without subsequent $E$. coli injection after either 3hour and 6-hour observation periods, respectively. Consequently, the data obtained represent the decreasing number of circulating $E$. coli resulting exclusively from clearance function which is not falsified by measurements of incalculable alterations due to translocated endogenous E. coli.

\section{High-Dose Lipid Infusion}

Concerning high-dose lipid emulsion, the elimination kinetics of bacteria from the circulating blood differed significantly between the groups (fig. 1). The rapid decrease of bacteria within the first $20 \mathrm{~min}$, which was observed in all groups, was followed by a delayed clearance with persisting numbers of $E$. coli in the Lipovenös and Omegavenös groups. In contrast to the controls in which blood cultures were sterile $50 \mathrm{~min}$ after 
Fig. 5. Counts of viable bacteria in spleen (a) and lung (b) homogenates taken $3 \mathrm{~h}$ and $6 \mathrm{~h}$ after injection of $E$. coli in the groups pretreated with low doses of lipid emulsions $\left(0.5 \mathrm{~g} / \mathrm{kg}\right.$ body weight) ${ }^{*}=\mathrm{p}<0.05$ versus controls, ${ }^{* *}=\mathrm{p}<0.01$ versus all other groups.

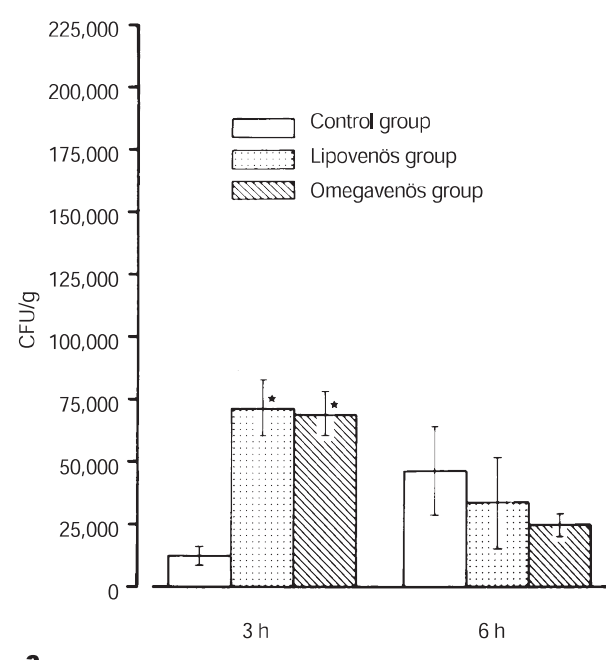

a

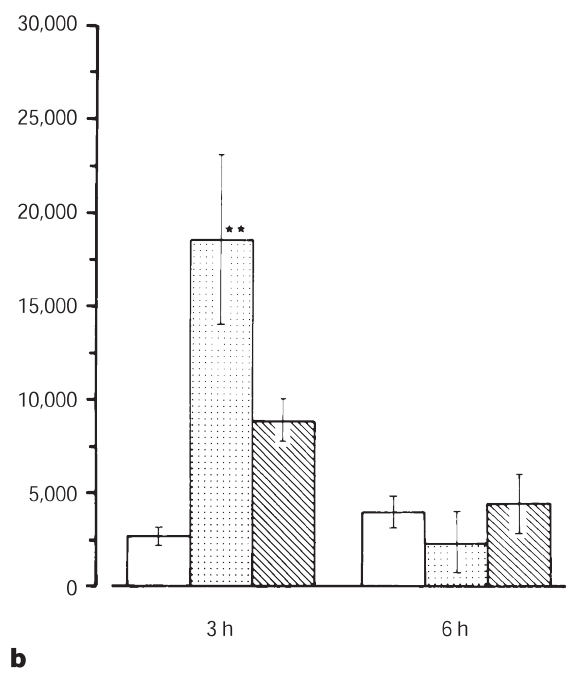

E. coli injection, bacteria could be grown from blood samples up to 180 min after $E$. coli injection in the Omegavenös-treated rabbits. However, in the Lipovenös-infused animals a delayed clearance with persisting numbers of $E$. coli could be observed lasting up to $300 \mathrm{~min}$ (fig. 2).

The examination of organ homogenates revealed differences in the distribution pattern of viable bacteria in the various groups. Cultures from tissues of the control groups showed the highest bacterial numbers in the liver $\left(234 \times 10^{3} \mathrm{CFU} / \mathrm{g}\right)$, whereas lower counts were found in the spleen $\left(12 \times 10^{3}\right.$ $\mathrm{CFU} / \mathrm{g})$. Only minor bacterial counts could be detected in lung $\left(3 \times 10^{3} \mathrm{CFU} / \mathrm{g}\right)$ and kidney $\left(0.5 \times 10^{3} \mathrm{CFU} / \mathrm{g}\right)$. In contrast to this pattern, significantly higher $(\mathrm{p}<0.05)$ amounts were found in the spleen after high-dose lipid infusion (fig. $3 a)$. Three hours after $E$. coli injection bacterial counts up to $150 \times 10^{3} \mathrm{CFU} / \mathrm{g}$ in the Lipovenös group and up to $203 \times 10^{3}$ $\mathrm{CFU} / \mathrm{g}$ in the Omegavenös group were found (fig. 3). Even 6 $\mathrm{h}$ after bacteria injection, 3-fold higher numbers of $E$. coli $\left(130 \times 10^{3} \mathrm{CFU} / \mathrm{g}\right)$ were noted in the Lipovenös group compared with the control values, whereas only $66 \times 10^{3} \mathrm{CFU} / \mathrm{g}$ could be detected in the spleen of Omegavenös-treated rabbits. The high colonization of the spleen after treatment with soybean oil emulsion was associated with significantly increased $(\mathrm{p}<0.01)$ amounts of bacteria in the lung $\left(29 \times 10^{3}\right.$ $\mathrm{CFU} / \mathrm{g}) 6 \mathrm{~h}$ after bacteria application. Infusion with fish oil emulsion resulted in markedly decreased numbers of $E$. coli in the lung $\left(<1.5 \times 10^{3} \mathrm{CFU} / \mathrm{g}, \mathrm{p}<0.02\right)$ and liver $\left(148 \times 10^{3}\right.$ $\mathrm{CFU} / \mathrm{g}, \mathrm{p}<0.05)$. In these animals, lower numbers of bacteria were found in all four organs $\left(216 \times 10^{3} \mathrm{CFU} / \mathrm{g}\right)$, differing significantly $(\mathrm{p}<0.05)$ from those numbers obtained $6 \mathrm{~h}$ after $E$. coli injection in the control $\left(411 \times 10^{3} \mathrm{CFU} / \mathrm{g}\right)$ and in the Lipovenös-treated animals $\left(408 \times 10^{3} \mathrm{CFU} / \mathrm{g}\right)$. The examination of kidney homogenates demonstrated no significant alterations in all groups.

\section{Low Dose Lipid Infusion}

Experiments with low doses of both lipid emulsions $(0.5 \mathrm{~g} / \mathrm{kg}$ body weight) demonstrated no significant alteration of bacterial clearance from the blood compared to control. Blood cultures of samples drawn 120 and 150 min after bacterial infection were sterile in the Omegavenös- and Lipovenös-treated group, respectively (fig. 4). However, compared to controls significantly higher amounts of $E$. coli were found in the spleen in both lipid treated groups $3 \mathrm{~h}$ after $E$. coli injection $\left(72 \times 10^{3} \mathrm{CFU} / g\right.$ in the Lipovenös group, $68 \times 10^{3} \mathrm{CFU} / \mathrm{g}$ in the Omegavenös group, fig. 5a). Analogously to the high-dose Lipovenös infusion, the low-dose challenge was accompanied by significantly higher $(\mathrm{p}<0.01)$ numbers of bacteria in the lung $\left(18 \times 10^{3} \mathrm{CFU} / \mathrm{g}\right)$, whereas lung bacterial counts in fish oil-treated animals did not differ significantly from controls (fig. 5b).

Six hours after $E$. coli injection, markedly reduced bacterial numbers were evident in the liver of Omegavenös- $\left(67 \times 10^{3}\right.$ CFU/g, $\mathrm{p}<0.01$ versus control group) and Lipovenös-treated animals $\left(74 \times 10^{3} \mathrm{CFU} / \mathrm{g}, \mathrm{p}<0.01\right.$ versus control group). The numbers of bacteria in spleen, lung, and kidney of lipid emulsion-pretreated animals were not significantly different from those obtained in the organs of the controls.

\section{Discussion}

Considering clinical and experimental evidence that dietary intake of $\omega$-3 FAs may influence the immune function of the RES and circulating phagocytes [22], we investigated whether or not blood clearance and organ distribution of systemically applied $E$. coli might be improved after infusion of lipid emulsions enriched with $\omega-3$ FAs in comparison to that of clinically applied $\omega-6$ FA emulsions. For this purpose, blood and organ clearance of bacteria were examined in rabbits treated with saline, fish oil (Omegavenös), or soybean emulsion (Lipovenös).

The intravenous administration of $E$. coli was chosen as a correlate of bacterial invasion from various origins, e.g. the gut, the urogenital tract, wounds or implanted catheters, into the 
circulating blood. In order to enable quantification of the clearance process, a defined number of $E$. coli was injected into the circulation. To exclude possible miscalculations resulting from incalculable numbers of bacteria being translocated from the gut, blood samples were taken prior to E. coli injection, and additional experiments were performed to determine whether or not Lipovenös or Omegavenös treatment itself leads to invasion of $E$. coli, particularly from the gut, into the blood and other organs during the observation period. These experiments revealed no invasion of endogenous E.coli into the blood, as evidenced by sterile cultures in our model. Hence, additional translocation of intestinal E. coli which may mask the effects of bacterial clearance function and tissue distribution could be ruled out. Thus, alterations in clearance function due to the applied lipid emulsions could be accounted for the differences in numbers of detected bacteria counted as CFU.

Clearance of bacteria followed a biphasic time course starting with a rapid phase described by an exponential-like decrease of $\mathrm{CFU}$ in the first few minutes. Afterwards, the clearance from blood became progressively slower. The rapid phase was identical in all groups, whereas the slow phase was significantly prolonged after pretreatment with high doses of Lipovenös and to a lesser extent in rabbits pretreated with high doses of Omegavenös. A possible explanation for the failure to completely remove bacteria from the circulation may be due to a RES blockade by the previously applied lipid emulsions, with consequently reduced phagocytosis and lysis capacity. One hint supporting this explanation are the increased levels of triglycerides in the sera of rabbits pretreated with high doses of soy or fish oil emulsion. The hypertriglyceridemia (about $2,000 \mathrm{mg} / \mathrm{dl}$ ) was obviously due to the high infusion rate (1 $\mathrm{g} / \mathrm{kg}$ body weight $/ \mathrm{h})$. In contrast, parenteral nutrition in human is restricted to a maximum rate of $0.2 \mathrm{~g} / \mathrm{kg}$ body weight $/ \mathrm{h}$, thus avoiding triglyceride concentrations above $500 \mathrm{mg} / \mathrm{dl}$. Due to the high intake of triglycerides, the reticuloendothelial cells may be saturated with lipids, which might result in a diminished clearance of bacteria. An interrelationship must be assumed between reticuloendothelial clearance and host defense against sepsis, since it has been repeatedly documented that there is a transient period of severe RES phagocytic depression following the clearance of large doses of foreign test colloids [23, 24] and coagulation products [25] which is associated with diminished hepatic phagocytosis and augmented extrahepatic localization of the systemically injected bacteria.

In all groups pretreated with lipid emulsion, it seems that within $3 \mathrm{~h}$ after bacteria injection an increased amount of injected bacteria is filtered out in the spleen. This increment might be related to induction of increased extrahepatic uptake of bacteria as a consequence of a decreased hepatic clearance rate. Additionally, an augmented recovery of injected bacteria was found in the lung of Lipovenös-treated rabbits. The reason for this cannot be discerned from our results, but alterations of leukocyte functions such as chemotaxis, phagocytosis, adherence and release of bactericidal enzymes has to be considered. The increased uptake of bacteria from extrahepatic organs, e.g. the lung, observed in the Lipovenöstreated animals might reflect a state of hyperphagocytotic activity. Accumulation and enhanced sticking of leukocytes and macrophages are well-known phenomena, which were observed in other experimental studies concerning depressed vascular clearance in cases of traumatic shock and surgical trauma [26-28]. In contrast to this, supplementation with $\omega-3$ FAs could improve RES phagocytosis, as suggested by an enhanced bacterial clearance from the blood and a significantly lower number of bacteria in the lung. The decreased amount of bacteria in the lung might be due to a reduced lung neutrophil recruitment in response to bacterial clearance in the presence of $\omega-3$ FAs. The reason for this could be a prevention of leukocyte/endothelium interaction through the inhibition of $\mathrm{LTB}_{4}$ biosynthesis and enhanced generation of antiadhesive forces after intake of $\omega-3$ FA-supplemented diet [4]. $\mathrm{LTB}_{5}$ generated in EPA-enriched PMN possesses a more than 10 -fold reduced chemotactic and PMN activiting capacity compared to $\mathrm{LTB}_{4}$ [12]. A decreased pulmonary number of bacteria can also be explained by a decreased number of circulating bacteria, possibly resulting from improved phagocytosis and lysis of bacteria in liver and spleen. $\omega-3$ FAs might affect phagocytic cell function by means of changes in membrane phospholipid content and reduced production of $\mathrm{PGE}_{2}$. EPA competes with $\mathrm{PGE}_{2}$ precursor $\mathrm{AA}$ for binding at the active site of cyclooxygenase, thus resulting in reduced production of $\mathrm{PGE}_{2}$, which is probably one important mediator of immunosuppression that follows major injury. Recent studies have shown that $\mathrm{PGE}_{2}$ suppresses various aspects of the immune response, including lymphocyte proliferation, lymphokine secretion, and phagocyte function [29-32], (fig. 1).

A series of functional alterations induced by diets enriched with $\omega-3$ FAs might contribute to the described effects, i.e. an increased production of cytokines [33], increases of cell-mediated immunity [16] and opsonization index [16] as well as an increase of antigen-induced lymphocyte generation [34, 35]. In animal experiments, Ertel et al. [36] observed an increased cytokine production (Il-1, IL-2), a reduced PGE 2 release from macrophages, and an improvement in both the capacitiy of antigen presentation and splenocyte proliferation following hemorrhagic shock in those animals which had been fed $\omega-3$ FAs instead of $\omega-6$ FAs. These results are in line with preliminary data of two clinical trials in which fish oil diets were shown to have restorative effects on the depressed cellular immunity of patients in intensive care units [37] and after major surgery [38]. However, a significant decrease in infectious complications or mortality in these patients could not be demonstrated. Nonetheless, a prospective clinical study in burned patients by Alexander et al. [39] showed that the use of a diet containing fish oil significantly reduced wound infection, shortened hospital stay, and reduced mortality compared with other standard enteral formulation. 
In conclusion, the present study suggests that the use of $\omega$-3 FAs seems to be a promising therapeutical approach for the improvement of immune function, thus reducing bacterial infection. However, further clinical studies are required to evaluate the effects of $\omega$-3 FAs in critically ill patients.

\section{Acknowledgments}

The authors thank A. Weber and H. Michnacs for excellent technical assistance, P. Müller for skillful graphic illustration, and T. Wieth for proofreading the manuscript.

This study was supported by a grant from the faculty of Clinical Medicine Mannheim, University of Heidelberg

\section{References}

1 Carrico CJ, Meakins JL, Marchall JC, Fry D, Maier BV: Multiple organ failure syndrome. Arch Surg 1986;121:196-201.

2 Fischer S: Dietary polyunsaturated fatty acids and eicosanoid formation in humans. Adv Lipid Res 1989;23:169-198.

3 Brown AJ, Pang E, Roberts DCK: Persistent changes in the fatty acid composition of erythrocyte membranes after moderate intake of n-3 polyunsaturated fatty acids: Study design applications. Am J Clin Nutr 1991;54:668-673.

4 Lehr HA, Hübner C, Finckh B, Nolte D, Beisiegel U, Kohlschutter A, Messmer K: Dietary fish oil reduces leukocytes/endothelium interaction following systemic administration of oxidatively modified low densitiy lipoprotein. Circulation 1991;84:17251731.

5 Chilton FH, Patel M, Fonteh AN, Hubbard WC, Triggiani M: Dietary n-3 fatty acid effects on neutrophil lipid composition and mediator production. Influence of duration and dosage. J Clin Invest 1993;91:115-122.

6 Urakaze M, Hamazaki T, Makuta M, Ibuki F Kobayashi S, Yano S, Kumagai A: Infusion of fish oil emulsion: Effects on platelet aggregation and fatty acid composition in phospholipids of plasma, platelets, and red blood cell membranes in rabbits. Am J Clin Nutr 1987;46:936-940.

7 Croset M, Bayon Y, Lagarde M: Incorporation and turnover of eicosapentaenoic and docosahexaenoic acids in human platelets in vitro. Biochem $\mathrm{J}$ 1992;281:309-316.

8 Bourre JM, Bonneil M, Dumont O, Piciotti M, Calaf R, Portugal H, Nalbone G, Lafont H: Effect of increasing amounts of dietary fish oil on brain and liver fatty acid composition. Biochim Biophys Acta 1990;1043:149-152.

9 Fischer S, Weber PC: Prostaglandin $\mathrm{I}_{3}$ is formed in vivo in man after dietary eicosapentaenoic acid. Nature 1984;307:165-168

10 Strasser T, Fischer S, Weber PC: Leukotriene $\mathrm{B}_{5}$ is formed in human neutrophils after dietary eicosapentaenoic acid. Proc Natl Acad Sci USA 1985;82:1540-1543.

11 Weber PC, Fischer S, von Schacky C: Dietary omega-3 polyunsaturated fatty acids and eicosanoid formation in man; in Simopoulos AP, Kifer RR, Martin RE (eds): Health Effects of Polyunsaturated Acids in Seafoods. Orlando, Academic Press, 1986, pp 49-60

12 Lee TH, Sethi T, Crea AEG, Peters W, Arm JP, Horton CE, Walport MJ, Spur BW: Characterization of leukotriene $B_{3}$ : Comparison of its biological activities with leukotriene $\mathrm{B}_{4}$ and leukotriene $\mathrm{B}_{5}$ in complement receptor enhancement, lysozyme release and chemotaxis of human neutrophils. Clin Sci 1988;74:467-475.
13 Koch T, Duncker HP, Klein A, Schlotzer E, Peskar BM, van Ackern K, Neuhof H: Modulation of pulmonary vascular resistance and edema formation by short-term infusion of a $10 \%$ fish oil emulsion. Infusionsther Tranfusionsmed 1993;20:291-300.

14 Koch T, Heller A, Breil I, van Ackern K, Neuho $\mathrm{H}$ : Alterations of pulmonary capillary filtration and leukotriene synthesis due to infusion of a lipid emulsion enriched with omega-3 fatty acids. Clin Intensive Care 1995;6:112-120.

15 Breil I, Koch T, Heller A, Schlotzer E, Grünert A van Ackern K, Neuhof H: Alteration of n-3 fatty acid composition in lung tissue after short-term infusion of fish oil emulsion attenuates inflammatory vascular reaction. Crit Care Med 1996;24:18931902

16 Alexander JW, Saito H, Trocki O, Ogle CK: The importance of lipid type in the diet after burn injury. Ann Surg 1986;204:1-8.

17 Barton RG, Wells CL, Carlson A, Singh R, Sullivan JJ, Cerra FB: Dietary omega-3 fatty acids decrease mortality and Kupffer cell prostaglandin $\mathrm{E}_{2}$ production in a rat model of chronic sepsis. J Trauma 1991;31:768-774.

18 Kinsella JE, Lokesh B, Broughton S, Whelan J: Dietary polyunsaturated fatty acids and eicosanoids: Potential effects on the modulation of inflammatory and immune cells: An overview. Nutrition 1990; 6:24-44.

19 Sandys GH: A new method of preventing swarming of Proteus sp. with a description of a new medium suitable for use in routine laboratory practice. $J$ Med Lab Technol 1960;17:224-233.

20 Abraham E, Chang Y-H: Effects of hemorrhage on inflammatory response. Arch Surg 1987;119: 11541157

21 Fink MP, Gardiner M, MacVittie TJ: Sublethal hemorrhage impairs acute peritoneal response in rats. J Trauma 1985;25:234-237.

22 Suchner U, Senftleben U, Felbinger T: Nichtenergetische Aspekte der Ernährung; in Lawin P, Peter $\mathrm{K}$, Prien T (Hrsg): Intensivmedizin, Notfallmedizin, Anästhesiologie. Stuttgart, Thieme, 1995, pp 178-205.

23 Biozzi G, Stiffel C: The physiopathology of the reticuloendothelial cells of the liver and spleen; in Popper H, Schaffner F (eds): Progress in Liver Diseases. New York, Grune \& Stratton, 1965, pp 166 191

24 Saba TM, Di Luzio NR: Reticuloendothelial blockade and recovery as a function of opsonic activity. Am J Physiol 1969;216:197-205.

25 Koch T, Duncker HP, Axt R, Schiefer HG, van Ackern K, Neuhof H: Effects of hemorrhage, hypoxia, and intravascular coagulation on bacterial clearance and translocation. Crit Care Med 1993; 21:1758-1764
26 Kaplan JE, Saba TM: Humoral deficiency and reticuloendothelial depression after traumatic shock. Am J Physiol 1976;230:7-14.

27 Saba TM, Antikatzides TG: Heparin induced alterations in clearance and distribution of blood-borne microparticles following operative trauma. Ann Surg 1979;189:426-432.

28 Koch T, Duncker IIP, Axt R, Schiefer HG, van Ackern K, Neuhof H: Alterations of bacterial clearance induced by endotoxin and tumor necrosis factor. Infect Immun 1993;61:3143-3148.

29 Marshall LA, Johnston PV: The influence of dietary essential fatty acids on the rat immunocompetent cell, prostaglandin synthesis and mitogeninduced blastogenesis. J Nutr 1985;115:1572-1580.

30 Goodwin JS, Ceuppens J: Regulation of the immune response by prostaglandins. J Clin Immunol 1983;3:295-310.

31 Parker CW: Leukotrienes and prostaglandins in the immune system. Adv Prostaglandin Thromboxane Leukot Res 1986;16:113-134.

32 Parker CW: Lipid mediators produced through the lipoxygenase pathway. Annu Rev Immunol 1987; 5:65-84

33 Watanabe S, Hayashi H, Onozaki K, Okuyama H: Effect of dietary alpha-linolenate/linoleate balance on lipopolysaccharide-induced tumor necrosis factor production in mouse macrophages. Life Sci 1991;28:2013-2020

34 Cerra FB, Alden PA, Negro F, Billiar T, Svingen BA, Licari J, Johnson SB, Holman RT: Sepsis and exogenous lipid modulation. JPEN 1988;12: 63S-68S.

35 Billiar TR, Bankey PE, Svingen BA, Curran RD, West MA, Holman RT, Simmons RL, Cerra FB: Fatty acid intake and Kupffer cell function: Fish oil alters eicosanoid and monokine production to endotoxin stimulation. Surgery 1988;104:343-349.

36 Ertel W, Morrison MH, Ayala A, Chaudry IH: Modulation of macrophage membrane phospholipids by $n-3$ polyunsaturated fatty acids increases interleukin-1 release and prevents suppression of cellular immunity following hemorrhagic shock. Arch Surg 1993;128:15-21.

37 Cerra FB, Lehman S, Konstantinides N, Konstantinides F, Shronts EP, Holman R: Effect of enteral nutrition on in vitro tests of immune function in ICU patients: A preliminary report. Nutrition 1990:6:84-87.

38 Lieberman MD, Shou J, Torres AS, Weintraub F, Goldfine J, Sigal R, Daly JM: Effects of nutrient substrates on immune function. Nutrition 1990; 6:88-91

39 Alexander JW, Gottschlich MM: Nutritional immunomodulation in burn patients. Crit Care Med 1990;18:S149-S153. 